\title{
OBSERVATIONS ON THE ECOLOGY AND EPIDEMIOLOGY OF XYLEBORUS DESTRUENS BLDF., THE NEAR-PRIMARY BORER IN TEAK PLANTATIONS IN JAVA *)
}

\author{
by
}

\author{
L. G. E. KALSHOVEN \\ Blaricum, The Netherlands
}

\begin{abstract}
I have great pleasure in dedicating this paper to my friend Ir. F. J. Appelman, who showed such a keen interest in all forest zoological matters during the long period he was connected with the Forest Service in Java. In fact he was the first to draw attention to the occurrence of the Xyleborus borer in the Bandjar district and he assisted me in every possible way to make my observations and experiments in the forest area in his charge.
\end{abstract}

\section{INTRODUCTION}

First observations of Xyleborus destruens as a borer of teak

While looking for a suitable plot for girth-increment investigations in a thriving 8-year old teak plantation near Batang, Central Java, in June 1918, officers of the Forest Research Institute discovered an unknown, rather conspicuous borer infestation of the trunks. The borer, recognized to be a Xyleborus species of $4 \mathrm{~mm}$ size, had attacked trunks showing still open Cossid holes and other very local wounds, but also several apparently perfectly sound trees. The wood was riddled with the tunnels which had resulted in severe technical damage.

The present author made further field observations during three short visits, September 1918-July 1919, in order to collect data on the extent of the injury, the habits of the borer and the course of the infestation.

Quite by accident I found the same borer-meanwhile identified as $X$. destruens Bldf. (RoEPKE 1919) -in some teak stands South of Malang in East Java, a locality at a great distance from the first. However, there was no opportunity to study this case in detail.

The first observations were officially reported in two subsequent annual reviews of crop pests (vaN

-) This paper was written in 1960 when I enjoyed a grant of the Netherlands Organization for Pure Research (Z.W.O.).-An abstract was read at the Eleventh International Entomological Congress at Vienna, August 1960. -A supplementary paper dealing with the gallery system and the development of the brood of Xyleborus destruens will be published elsewhere.
HaLl 1918 p. 11,1919 p. 11). In a paper published early in $1920 \mathrm{I}$ gave a full account of the results of the preliminary investigations.

Once the attention had been drawn to the infestation of living teak trees by the small borer, information was obtained that the tunnels had already been noticed during thinning operations in teak plantations near Bodja, situated east of Batang in the same part of the country, in 1917. I visited this area in August 1920 at which time the borer was no longer active but many traces of the infestation, wide-spread in the 20-25 year old plantations, were still to be seen. I revisited the Batang locality in November 1922 when no signs of a fresh attack were to be found and most of the traces of the former infestation had vanished.

Some new observations of the borer's occurrence in different places of the teak area followed in 1924 1928 but these were very local attacks affecting only a few trees (see p. 16). Traces of former borer activity were also found in timber lying in depots, where, so far, they had scarcely attracted the attention of the forestry personnel or the timber merchants.

New outbreaks in the early thirties and later

In June 1930, F. J. Appelman, senior Conservator of Forests in the Tasikmalaya district in West Java, reported on a severe borer-infestation in a 6-year old teak plantation near Tjiamis/Bandjar. The description given made it evident at once that the borer was again $X$. destruens. I visited the area for a few days in July and similar inspections and observations were repeated with intervals of some months.

Medio 1931 a new report was received about the occurrence of an unusual primary borer in teak which 
proved to be $X$.destruens, this time observed in a complex of more or less mixed teak plantations near Bruno in the Gunung Wayang Forest Reserve at some 400-600 m altitude in the district of Kedu, in the southern part of Central Java. A two days' visit was paid to this complex at the end of October. A large percentage of 7-9 year old teak was found to be attacked (see p. 14).

In view of these observations it was proposed to the Director of Forestry to inform the managers of forest ranges where teak was grown about the matter and to advise them to be on the look-out for the occurrence of the new borer infestation in their areas. A circular letter to this effect was distributed at the end of 1931.

This resulted in the report of three additional places of distribution of the borer, viz. in some of the widespread plantations in the Banyumas district, bordering Tjiamis/Bandjar to the East, in a 14-year old locally infested plantation near Tjikalong-Kulon, and in a 5-year old plantation Tjidjawer near Tjipatat, where only a few infested trees had been detected; the last named places were both situated in the hills rising to some $500 \mathrm{~m}$ in the Bandung district in West Java.

In all other cases, mainly referring to the proper teak area of Central and East Java, the answers were in the negative, with two exceptions. And here, in Ponorogo and Padangan, the investigation of the material submitted showed that a slight infestation of young teak by the common twig- and stemborer $X$. morigerus Bldf. had been mistaken for an attack by the much larger trunk borer $X$. destruens.

Additional information was supplied by the Forest Service about old and new localities where the borer had been found in Kedu and Banyumas in 1933/1934. In both districts a more or less regular and chronic infestation appeared to occur in the scattered teak plantations. In July 1935 a report was received about the occurrence of the borer in a small range of teak plantations growing at the S.W. foot of Mount Semeru, North of Dampit. By our request the forest officers concerned sent the main details, which again contirmed the observations made elsewhere. A few facts about the borer situation were mentioned in annual reports of forest pests (KALSHOven 1934/1936).

After the war alarming news about an outbreak of $X$. destruens was received at headquarters in Bogor, in 1948. It appeared to refer to two ranges of plantations of small extension situated on the S. slope of the Mount Idjen Complex at $400-700 \mathrm{~m}$ (see further p. 15 and Ferguson 1948).

An extensive survey on the prevalence of the borer in different ranges made on the instigation and under the supervision of vaN Alphen DE VeER in 1952 1954, mainly dealt with the same places where outbreaks were known to have taken place (see p. 15).

\section{Continued observations in Bandjar}

During the visits paid to the Bandjar area which included plantations up to 14 years old, it soon appeared that the infested range was much larger than at first suspected, and that the outbreak of X.destruens had been expanding annually for some time and was developing a chronic nature. Therefore it was decided, medio 1931, to include regular observations on this infestation in the programme of forestentomological work, and a local native assistent of mantri rank was appointed to carry out countings, to mark trees, to make regular inspections and suchlike pursuits.

An extra credit was voted for the continuance and intensification of the investigations in 1932, so that a second native helper could be appointed. This credit was prolonged for some years.

The first observations were carried out on the same lines as those already made in Batang in 1919, but on a much larger and more varied scale.

Other points of entomological and silvicultural interest were included in the programme in the course of the years. What subjects were mainly dealt with may be inferred from the headings of the following paragraphs. The investigations were continued up to 1938.

\section{ECOLOGY OF THE BORER}

\section{Preference for particular host specimens and trunk-sections}

The observations in different localities where plantations and natural stands of teak of various ages were found, have repeatedly shown that the trees are not attacked before they have grown to a girth of at least $20 \mathrm{~cm}$, which size in suitable conditions is not reached until a plantation is at least 3 or 4 years old. Trees of $30-60 \mathrm{~cm}$ girth appear to be very susceptible, and may be found in thriving plantations of 6-10 years old. There appears to be no limit to the girth for a tree to be still attacked, as the borer has been found in a trunk measuring $80 \mathrm{~cm}$ in diameter at breast height (see p. 11).

Already during the investigations of the first noticed infestation in 1918 it became evident that the borer attack was not equally spread over all the trees in the stand but on the one hand it was more or less concentrated on the most forward trees, even when ap- 
parently entirely sound, and on the other hand it frequently occurred in portions of the trunk showing a wound. Moreover, the degree of infestation appeared to be larger in the basal parts of the trunks than higher up.

First some data may be given here about the preference of the borer for the fastest grown trees in a stand.

In a plot in the infested plantation of Batang, which had been surveyed by the silvicultural team, $11 \%$ of the dominating trees had been attacked, $4 \%$ of the trees with partially suppressed crowns, and $0.7 \%$ of the trees classified as suppressed or backward. The diameter of the infested trees ranged from $8-24 \mathrm{~cm}$ and was $16 \mathrm{~cm}$ on an average, those of all trees in the stand combined ranging from $4-24 \mathrm{~cm}$ and being $12 \mathrm{~cm}$ on the average.

Similar proportions were repeatedly found where measurements were taken in later outbreak areas.

In one instance, where 1000 trees were measured in plots of 6-year old plantation in Bandjar which had a $24 \%$ infestation, the average girth of the infested trees was $43 \mathrm{~cm}$ against $39 \mathrm{~cm}$ for the noninfested trees.

This peculiarity of the best developed trees in a stand being attacked more than backward specimens it would be possible to substantiate by many more figures.

In order to verify the other observations of the degree of infestation being more concentrated on the basal parts of the trunks, in each of six plots the number of holes was counted on some 75 infested trees from the base to $1.75 \mathrm{~m}$ counting them separately for every $25 \mathrm{~cm}$ of trunk length. The plots were selected in six different plantations two of them 6 years and 6 months old, two one year older, and two 8 years and 6 months old, all situated in the Bandjar area. In these 6 instances the holes appeared to be distributed much in the same fashion, viz. in this proportion:

$\begin{array}{rrrr}0-25 \mathrm{~cm} & 21 \% & 100-125 \mathrm{~cm} & 12 \% \\ 25-50 \mathrm{~cm} & 17 \% & 125-150 \mathrm{~cm} & 11 \% \\ 50-75 \mathrm{~cm} & 15 \% & 150-175 \mathrm{~cm} & 10 \% \\ 75-100 \mathrm{~cm} & 14 \% & & \end{array}$

The figures show that the lowest $25 \mathrm{~cm}$ of the trunks carried more than $1 / 5$ of the holes occurring up to $1.75 \mathrm{~m}$ height, $1 / 2$ of the holes being found in the part up to $75 \mathrm{~cm}$.

This preference of the borer for the basal portion of the trunks may be said to point in the same direc- tion as the selection of the thickest trees in the young plantations.

\section{Correlation between borer attack and the presence of wounds}

The third special feature of the infestation recognized early and already mentioned is the frequency of the borer starting its attack in or near open wounds in the bark.

These wounds may have very different origins, but, as far as conditions in the Bandjar area go, most of them have appeared to consist of holes caused by the Cossid, Xyleutes ceramica Walk., called "oleng-oleng" in the teak area of Java and "bee-hole borer" in India and Burma (Pl. I, fig. 1, 3). Its larva makes a short tunnel which has an upward direction and is used for shelter as the borer actually feeds on the young tissues of the bark and wood near the entrance (later to become the exit of the moth) and on the callus which is constantly produced by the cambial zone in the process of closing the wound. In normal cases little more is seen outwardly than a slight swelling in the bark from which a little sap oozes and small quantities of granular excrements are ejected. The Xyleutes holes occurring in the axil of a fork or at the base of a small dwindling side branch have appeared to lead to badly closing, sap producing wounds which particularly attract the X. destruens beetle (Pl. II, fig. 14). Furthermore the Xyleutes wounds are not infrequently enlarged by wood-peckers which cut one or two square holes above the entrance in order to reach the larva in its shelter. Really bad wounds are formed by large squirrels that gnaw a gap into the sapwood for the same reason, viz. to expose the hole and secure the fat larva. This latter feature has only been observed at Bandjar in the neighbourhood of old mixed forest.

Another primary borer infestation rather frequently occurring in the Bandjar area and attracting X. destruens is caused by the Lamiid Monohammus rusticator Fab. The larva tunnels in the fleshy parts of the bark, eventually forming a hook-like cell in the outer wood, from which the beetle emerges biting a round hole to the outside (Pl. II, fig. 13).

A third, less frequent insect-damage to the trunks in the Bandjar plantations and evoking early $X$. destruens attack has been found to be caused by Coptotermes curvignathus Holmgr. This termite attacks the trees simultaneously in the core, having gained access in the root-system, and from the outside, where holes are gnawed in the bark and wood under cover of a clay coating enveloping the base. While most species of trees succumb to the attack, young vigorous teak 
trees are not killed but are abandoned by the termite after some time. However, the wounded parts remain moist for some time.

A kind of primary damage caused by fungi and commonly occurring in the Bandjar area is the killing of the cambial zone and bark at the root collar by a root disease. These trees have proved to be attractive to the borer as long as they still bear full foliage (see p. 10, 17).

Wounds of another particular type, met with in the Bandjar area and initiating the borer attack, consist of long, vertical, badly healing fissures in the trunk, looking not unlike the frost cracks occurring sometimes on trees in Europe. On the outside they appear like vertical ridges raised by callus growth and covered with an abundance of muddy and even tar-like matter (Pl. II, fig. 7 and 12). The wood along the cracks is very moist and discoloured, the core of the tree showing dry rot. The origin of these defects of the teak trees is not known but possibly they are caused by severe torsion of the trunk during gales.

Other damage by gales, like breakage, has also been found to be followed up by the borer attack. The not uncommon damage of groups of trees in the plantations by strokes of lightning must also be mentioned in this connection.

In some cases it has been found that the beetle also may enter the trunk at the place where a snag of an old side branch occurs and is not yet closed by the bark (PI. II, fig. 14).

Finally man made-wounds, for instance those resulting from too deeply cut markings on trees in the preparation of thinning operations, have also proved to invite the beetles to make their entrance in the gashes.

The attraction of the beetle to wounded trees, however, is not so strong that they are all attacked by it. In fact, only 20 to $50 \%$ of the damaged trees may be found infested in a stand, against some 10 to $20 \%$ of the sound trees. Therefore of every 3 or 4 borerinfested trees one tree may show traces of former damage. The total percentage of more or less damaged trees varied from 8 to $25 \%$ in the plantations of the Bandjar area at the time.

\section{Proportion of tunnelled sound and wounded parts}

In the foregoing it has been established that the borer attack is more or less concentrated on the lower portions of the trunk as well as on parts showing open wounds. In order to find out how these preferences interacted and in what proportion the infestations occurred singly or in combination, two hundred trees were investigated in a 4-year old plantation in Bandjar, November 1932. After a tree had been felled the trunk was split over its entire length and the extent of the tunnelled portions and the location of the defects were entered on rough sketches, divided into half meter lengths. This splitting of the trunks was very useful in detecting defects in the wood which were not clearly visible from the exterior.

The data obtained for the various sections were added up and the percentages calculated. The figures have been entered in table 1 and the diagram in Fig. 1 is based on them.

TABLE 1. Proportion of originally sound and damaged wood in 200 trunks of 4-year old infested trees

\begin{tabular}{|c|c|c|c|c|}
\hline \multirow{3}{*}{$\begin{array}{l}\text { Place of section } \\
\text { above the } \\
\text { ground-level }\end{array}$} & \multicolumn{4}{|c|}{ Percentages of the sections } \\
\hline & \multicolumn{3}{|c|}{ containing: } & \multirow{2}{*}{ sound } \\
\hline & bore-holes only & wounds and bore-holes & wounds only & \\
\hline $6.0-6.5$ & 0.0 & 0.5 & 0.9 & 99 \\
\hline $5.5-6.0$ & 0.5 & 1.0 & 1.0 & 97.5 \\
\hline $5.0-5.5$ & 1.0 & 1.0 & 1.5 & 96.5 \\
\hline $4.5-5.0$ & 1.5 & 1.5 & 2.0 & 95 \\
\hline $4.0-4.5$ & 2.0 & 2.5 & 3.0 & 92.5 \\
\hline $3.5-4.0$ & 3.0 & 3.0 & 4.0 & 90 \\
\hline $3.0-3.5$ & 5.0 & 6.0 & 5.5 & 83.5 \\
\hline $2.5-3.0$ & 9.0 & 11.0 & 6.5 & 73.5 \\
\hline $2.0-2.5$ & 13.0 & 19.0 & 7.0 & 61 \\
\hline $1.5-2.0$ & 17.0 & 29.5 & 7.5 & 46 \\
\hline $1.0-1.5$ & 21.0 & 39.0 & 6.0 & 34 \\
\hline $0.5-1.0$ & 24.0 & 48.0 & 5.5 & 22.5 \\
\hline $0.0-0.5$ & 26.0 & 53.0 & 5.0 & 16 \\
\hline
\end{tabular}


They show that the percentage of wounded as well as borer riddled parts is largest at the very base, even occurring in $80 \%$ of the trees, but gradually diminishes towards the top. Infestation by the borer becomes negligible above $5 \mathrm{~m}$ and does not occur at all above $7 \mathrm{~m}$.

The part of the sections showing wounds and infested by the borer is about twice as large as the sound parts attacked in the basal region. The originally sound wood infested by the borer becomes proportionally more important from $1.5 \mathrm{~m}$ up and equals the doubly damaged parts at about $3 \mathrm{~m}$. The wounded sections not invaded by $X$.destruens are small over the whole length, gaining somewhat in importance from 1-3 m.

A general conclusion to be derived from the figures is that the concentrated infestation of the basal parts of the trunk may not solely be due to the fact that these parts of young trees first grow to a thickness suitable for the breeding of the borer, but that it may partially be attributed to the frequent occurrence of wounds in these parts.

\section{Attraction of the borer to intentionally wounded trunks}

Some experiments were carried out on the possibility of attracting the borer to trees wounded on purpose. It was expected that in this way insight might be obtained into the habits of the beetle and concerning the infestation of trees under somewhat controlled conditions. Moreover we might find out whether such trees could be used as traps.

Experiment No. 1. On selected trees in a 4-year old, infested plantation in Bandjar the bark was removed in patches of $3 \times 6 \mathrm{~cm}$ and a hole bored in the centre to make the wounds somewhat resemble the injuries caused by the Cossid borer (Pl. II, fig. 9 and 10). Two or four of these wounds were made in the sections of $0.5-1 \mathrm{~m}$ above the base, in 8 originally sound trees and 8 infested trees of the same age and size, and the same was done in series of 15 sound and 15 infested trees in another plot, in December 1930. In February $193172 \%$ of the originally sound trees showed the borings of $X$. destruens in $60 \%$ of the artificial wounds, while recent borings were found in $96 \%$ of the same wounds on all trees already infested. The average number of holes per wound-patch was 2.5 and 6 respectively, for the two categories.

This clearly shows that the borer can be induced to attack trees which have first remained free from infestation, but that it is more readily attracted to or spreads more easily on trees already harbouring it in other parts.

In May 1931 the infestation had spread to $96 \%$ of the originally sound trees and to $77 \%$ of their wounds. How-

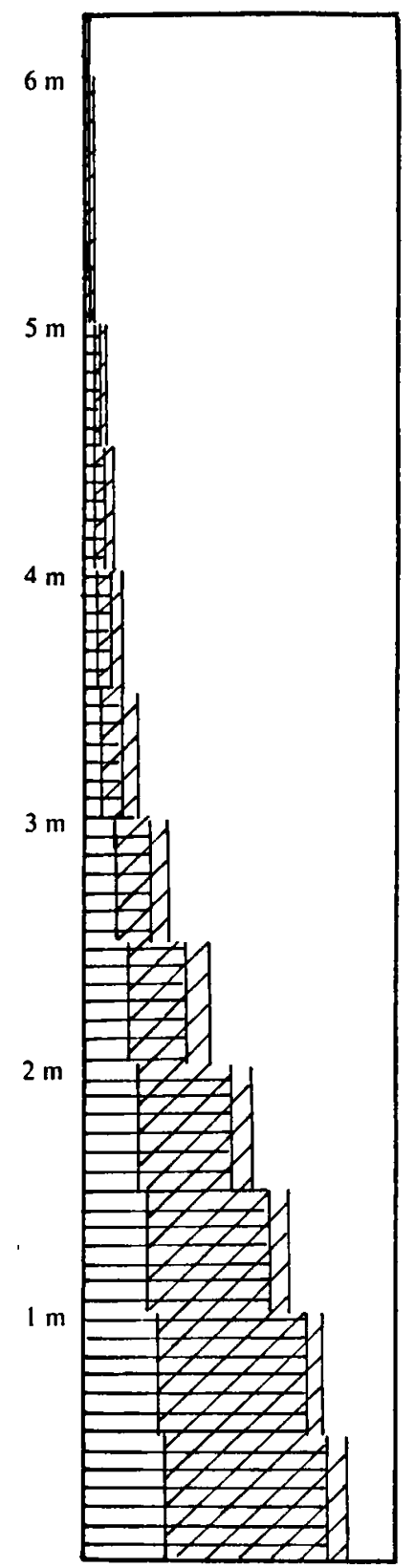

Fig. 1. Infestation of originally sound and damaged parts of 4-year old teak trunks, from the base up to $6 \mathrm{~m}$. The cross-shaded portions are tunnelled; those obliquely shaded carry old wounds; no shading means sound timber.

ever, only about half of the tunnels were really deep and apparently inhabited, on the other hand several recent holes had been bored in the trunks outside the wounds proper. During inspections in July and September it was found that more tunnels had been discontinued, but activities in numerous other holes were still going on. In July 1952 the purposely provoked infestation of eighteen months ago appeared to have developed into a lasting one 
for $70 \%$ of the formerly sound trees, and it did not differ in appearance from the long standing infestation on trees attacked in a spontaneous, unprovoked manner. The artificial wounds had not yet closed at that time but still presented slits of $1 / 2-2 \mathrm{~cm}$ broad and 8-15 cm high.

An unexpected, interesting feature had presented itself in the distribution of the newly bored entrances along the margin of the 3 months old, artificial wounds, in February 1931. Of the 383 holes noted $49 \%$ was found along the $3 \mathrm{~cm}$ broad, horizontal upper margin of the rectangular wounds, $37 \%$ along the two vertical margins, together $12 \mathrm{~cm}$ long and only $14 \%$ along the lower margin. Figure 2 gives the exact number of holes counted on the different parts of the wounds.

This unequal distribution was thought to have some connection with the much more vigorous callus growth along the top-margin of the wounds, this being attended by a higher moisture content of the tissues.

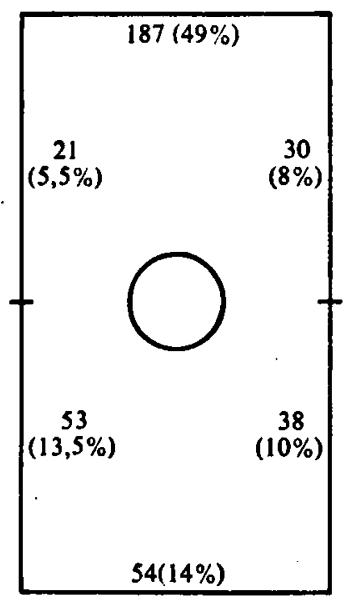

Fig. 2. Distribution of holes along the margin of artificial, $3 \times 6 \mathrm{~cm}$, wound.

Experiment No. 2. In May 1931 a deep transverse slit, $7 \mathrm{~cm}$ broad and $1 \mathrm{~cm}$ high, was cut in the base, ca. $0.5 \mathrm{~m}$ above the ground, of some 10 sound trees in a 4-year old infested plantation. (Pl. II, fig. 8). This was done in order to investigate whether the beetles might have some preference for entering the trunk below the cut where the sap flow had been interrupted. In July 7 trees had attracted beetles, most of which had made their entrance in the slit itself, where they could not be counted, a few had bored in the upper margin of the wound, 5 in the bark under the wound and 3 in the bark above or beside the slit. Notwithstanding some hindrance by activities of termites and ants in the deep cuts so near the soil surface, two more trees had become infested in September. By July 1932 all 10 trees showed a more or less heavy infestation of the base, most of it up to 1.5 or $2 \mathrm{~m}$, while the infestation had been extended up to $3 \mathrm{~m}$ and more in 6 trees, although the wounds had practically closed by that time. The holes were mostly situated on the same side of the trunk as the wound.

Experiment No. 3. A preliminary observation had shown that when the bark of a teak tree is firmly hit with a hammer, the underlying tissues of the cambium zone were killed and the patch of bark covering the spot also died.
Borer infestation had been found to follow this injury occasionally.

It was thought that this might provide another method to attract the borer to selected trees and particular sections of the trunk. Fifty trees of $24-40 \mathrm{~cm}$ girth, half of them sound, the other half having Cossid holes, were treated for a trial in a 5-year old infested plantation. The bark was hammered in strips of $10 \mathrm{~cm}$ in 2 or 3 places, these strips and wounds if any being covered with gauze to achieve a better spread infestation on the trunk. However, the experiment was a failure. Only in two originally sound trees and in three trees with Cossid wounds a single hole of X.destruens appeared and only in three instances out of these five the boring was continued and a completed gallery formes. The experiment clearly showed that an infestation cannot always simply be evoked in any tree which has been passed over by the borer in its natural occurrence.

Experiment No. 4. In July 193350 trees in a 7-year old plantation were marked for fortnightly observation, one third of them being sound and two thirds already infested. In all of them two holes of $1.5 \mathrm{~cm}$ diameter were drilled, the holes then being fitted with a zinc tube to prevent a too early occlusion by callus growth. After 4 months only one of the originally sound trees had been attacked by the borer, viz. by two beetles, whilst increase of holes was found in a dozen of the infested trees. At the end of the rainy season-9 months after the beginning of the experiment-only one fourth of the sound trees had one or two holes (in one instance 7), against an average of 9 additional holes in nearly all the trees which had already harboured the borer.

This type of wounding, therefore, appeared to be far less attractive for $X$. destruens than those used in experiments no. 1 and 2 , notwithstanding the fact that sap had been seen constantly leaking from the zinc tubes.

No attraction of the borer to dying trees. Continuation of boring in felled hosts

In agreement with its preference for fast growing, vigorous trees the borer has appeared to be not or only slightly attracted to weakened or dying host specimens. This was observable in various ways in the Bandjar plantations. Here trees slowly dying from root-disease were not unfrequently found, as already mentioned. Where these trees had become infested by the borer at a time when the root-fungus attack was in its initial stage, no increase of the borer infestation occurred any more after the bark and cambium had become killed and rotten all around the root collar, and the tree had begun to shed its leaves. The still green trunks mainly harboured secondary borers tunnelling in the cambial zone, like the larvae of the Cerambycid Xylotrechus buqueti C. \& G.

In like manner $X$. destruens was not observed in parts of trunks and branches which were being killed by the bark destroying fungus Corticium salmonicolor, 
although these parts often appear to be particularly attractive for other ambrosia beetles.

Another example was formed by teak trees struck by lightning and being killed "in full sap". Such trees of various timber species and palms have appeared to attract a number of ambrosia beetles and other secondary borers. However, where the borer fauna of lightning-struck teak trees was investigated in the outbreak area $X$. destruens was not found or in small numbers only. Some infestation, however, occurred in trees which had not been killed outright including the roots and were sprouting at the base from adventitious buds.

Furthermore it is of much importance that the borer was never observed to propagate in newly felled trees nor in felling areas, where deep cuts had been made through the bark and sapwood of the tree-bases, a common practice in Java to start the drying of the timber in the standing trunk, in order to diminish its weight for later transports.

The unattractiveness of trees ringbarked or dying from some cause or other was fully confirmed by an experiment in which the bark was removed on purpose over $2-5 \mathrm{~cm}$ near the base in a number of young trees in the outbreak area of Bandjar. Scarcely any infestation by the borer followed this operation.

The borer was found, however, albeit in small numbers, in large, fresh billets of teak kept in the shadow of a moist forest in Bandjar.

When infested trees were cut and the trunks not removed from the forest the borer remained active for some time extending its galleries-as shown by the expelling of fresh frass-while still some eggs were produced and the larvae and pupae completed their development. Even where the trunks had been split in two pieces the work of the borer had not stopped after two months, at what time part of the bark was still green and the wood still moist, particularly so during the rains.

The stumps of trees in which the borer had extended its galleries into the very base before they had been felled, also showed its continued activities, even after the bark had already been destroyed by termites and other agencies.

\section{Infestation of mature trees}

As mentioned in the introduction, the borer, soon after its discovery in C.Java, was also found in E.Java, South of Malang, where teak occurred in small areas. Here the borer was not only observed in a few plantations but also in mature trees in high forest. Some wounded places on trunks, about $30 \mathrm{~cm}$ thick, and showing brown, partially dried up discharge along the wounds of various shapes, proved to be infested by it (Pl. I, fig. 4 and 5). In one case a similar spot was noticed $4.5 \mathrm{~m}$ high on the trunk of a tree which was $80 \mathrm{~cm}$ in diameter at breast height. These cases were not further investigated.

Quite by accident, however, bore-holes, soon recognized to originate from a former attack by X. destruens were found in logs cut from a big teak tree, some $50 \mathrm{~cm}$ in diameter, which had been felled in the written-off remnants of a "natural" stand, estimated to be at least a hundred years old, in the forest of Tjomal, South of Pemalang, in 1927. The wood of the hollow base of the tree was riddled by the tunnels which were numerous also in the first $3 \mathrm{~m}$ of the bole, decreasing in number at $3-6 \mathrm{~m}$ height. This was reported by a conservator of forests who, paying further attention to the matter at my request, found that some other timber extracted from the same stand had the same holes and that an estimated 3 to $4 \%$ of the standing trees had been affected. The shot-holes were then also found in timber coming from a plot of a more secondary type in the same area, where the teak trees stood dispersed among other tree species, mainly Dillenia pentagyna. The teak trees yielded logs of $20-30 \mathrm{~cm}$ in diameter. A third plot stated to be infested was an apparently former cultivation, some 75 or 85 years old and standing quite isolated from the main complex but bordering a natural mixed forest of 100 ha. All three places were situated in the hills at some $300 \mathrm{~m}$ altitude.

\section{Theobroma cacao as a host tree}

BLANDFORD who described Xyleborus destruens in 1896 mentioned the receipt of a good series of the beetles from Java with the note that it was a pest of the cacao tree, the reporter not being named. As recently came to light, the beetle was also collected from the cacao tree by A. Zimmermann, at Bogor, W.Java, in 1900 (Kalshoven 1959). Zehntner (1901) mentioned a $4.5 \mathrm{~mm}$ large, red-brown species as being one of the Scolytidae occurring in numbers in cacao trunks suffering from "cancerous" patches in Central Java. This species, certainly X. destruens, was reported to be always the first on the scene and, after entering diseased wood also to penetrate in still sound portions of the trunk. He assumed that they were carrying spores of fungi which speeded up the work of destruction. Again, Roepke in 1919 confirmed the occurrence of this infestation. He wrote: "Xyleborus destruens BLDFD. ist eine Scolytide, die auf Java ganz allgemein in alten Kakao-Anpflanzungen auftritt. Die Käfer entwicklen sich nämlich zahlreich in alten stark vom Krebs befallenen Kakao-Stämmen, 
und zwar leben sie in dem kranken erweichten Gewebe, dasselbe mit zahlreichen Gängen durchsetzend. Aus den vielen Bohrlörchern kommen zentimeterlange Würstchen, weisslichen, lose zusammenhängenden Bohrmehles zum Vorschein; dieses Symptom ist charakteristisch für das Krankheitsbild. In gesundenem Gewebe sowie in andern Holzarten habe ich diesen Käfer nicht angetroffen." (Pl. I, fig. 6.)

Since 1919 the beetle has not been reported any more from cacao plantations in Java. Perhaps no attention was paid to it by planters and entomologists, or the gradual replacement of trees of the Crivllo type (Theobroma cacao) by hybrids of this species with the Forastero cacao (Th. leiocarpa) may have something to do with it.

However, the British Museum in London has a series of the beetle, including a male, taken "ex stem of cacao tree" by J. L. Froggatr in Rabaul, New Britain, IX.1940.

I may remind the reader that the cacao tree is not native to the Orient and that two other borers are to be found in the living trunks in Java, viz. the Lamiid Glenea novemguttata Cast. and the large Buprestid Chrysochroa bicolor F. The wood is rather soft.

Other host trees besides teak and cacao

During incidental collection work on Scolytidae carried out in the course of the years (KaLSHoven 1958) in Java, $X$. destruens was found only twice in trees other than teak, viz.:

In a living trunk of Albizzia saponaria-a species originating from the Moluccas-, the infestation occurring along the margin of an old wound caused by larvae of the Cerambycid Xystrocera festiva Pasc., the entrance holes being made where the wood was exposed or still covered with bark, up to $3 \mathrm{~m}$ high on the trunk; Botanical Gardens, Bogor, XII.1925.

In a broken, multiple-infested trunk of tjaringin, Ficus ?benjamina, at Tapos, N.W. slope of Mount Gedé at $800 \mathrm{~m}$, I. 1933.

To these records may be added the find of X.destruens in kibantjet, Turpinia pomifera, at Baturraden on Mount Slamat in Central Java at some $1000 \mathrm{~m}$ by F. C. Drescher, IV 1930, which has already been reported by SCHEDL (1951).

During field work on X.destruens my staff and I made a special effort to find other host trees and breeding places of the species besides the teak tree. A search was made for it in newly dead, borer-infested trees in the mixed primeval forest of the Mount Gadung Reserve, adjacent to the teak plantations in the Bandjar area, XII. 1933. All this, however, had little result as may be seen from the complete data following here:

Infestation of five massive trees of Albizzia falcata. in two of them in portions of the trunk attacked by larvae of Xystrocera festiva. The crowns of the Albizzia trees formed the highest storey of the canopy of a nine-year old mixed plantation in which an outbreak of the borer had taken place. The infested $A$. trees were the best developed, several slenderer trees not being attacked. Reforestation area on Mount Wajang, near Bruno in the district of Kedu, X. 1931.

A few holes in a badly damaged tree of Erythrina lithosperma, mainly infested by Xylebortus perforans and other species. Same locality.

Some holes made in gashes afflicted on the base of a big Sarcocephalus cordatus of which the crown had broken down; only a single beetle found with no evidence of the occurrence of a complete gallery system. However from the broken top-part which lay on the ground and harboured a large fauna of shot. hole borers, 11 specimens of $X$. destruens including a male, were collected, in company with some 10 other species of Xyleborus and Platypodidae, several of which were far more abundant. Bandjar, VII. 1932.

In a dying "kalapatiung" tree-belonging to the Myristicaceae, probably Horsfieldia glabra or $\mathrm{H}$. irya $-30 \mathrm{~cm}$ in diameter; death caused by attack of Coptotermes curvignathus Holmer. After the felling of the tree a tunnel was found at the level of the cutting near te base, no further tunnels being detected when the trunk was split longitudinally, but $X$. emarginatus Eichh. and Platypodidae were abundantly present, Bandjar VIII. 1932.

In a "tjalik angin" tree-one of the common $\mathrm{Eu}$ phorbiaceae, Macaranga sp. or Mallotus sp.-, $36 \mathrm{~cm}$ in diameter, standing at the forest border and attacked by Coptotermes curvignathus but still bearing its foliage. The base of the tree, split into pieces, showed X. destruens tunnels between the cavities and galleries of the termite. Wood smelling very badly. Bandjar VII. 1932.

In dead "randu alas" tree, Gossampinus heptaphylla, $35 \mathrm{~cm}$ in diameter; one specimen or X. destruens found in a sample of 65 ambrosia beetles extracted from the trunk and including at least 9 species, some of them predominating. Bandjar VII. 1932.

In a dying "kibadjing" tree-botanical species unknown-showing large, corroded holes in the base; no further details. Bandjar, I. 1932.

In a small tree of Trema orientale, $8 \mathrm{~cm}$ in diameter, a single hole of $X$. destruens was found near a wound cut by a wood-pecker to reach a large borer in the wood, probably the larva of the Lamiid Apriona 
flavescens Kaup., which has been found in living Trema trees in other instances. Bandjar, X. 1933.

In a young Vitex pubescens, diameter $19 \mathrm{~cm}$, infestation by $X$. destruens from the base up to $4 \mathrm{~m}$ but particularly at $40-60 \mathrm{~cm}$ and $190-290 \mathrm{~cm}$ above the ground; in a plantation near Madjenang, Banyumas, XII. 1935 (reported by personnel of the Forestry Service).

A few beetles in two billets sawn from a large Artocarpus elastica log. The billets had been kept, with other pieces, in the moist forest for the purpose of observations on shot-hole borer attack. They had attracted a number of other species of ambrosia beetles. Bandjar, II. 1933.

In specimens of Acacia oraria-a species introduced from the island of Timor-standing along the border of a 10-year old teak plantation where an outbreak of X. destruens had developed, as reported by the Forest Conservator P. K. Heringa, on the S. slope of Mount Semeru in East Java, VIII. 1935. The Acacia trunks had a diameter of $12-16 \mathrm{~cm}$ and appeared to be attacked in the base near wounded patches.

Besides these records from Java, there is one from Sumatra, viz. of Myristica fragrans, the nutmeg tree, Manindjau, III. 1931 (already mentioned by ScHEDL, 1942). Only a single specimen of $X$. destruens was found in the limbs collected from trees suffering from "premature death". The cause of the disease remained unexplained but bark-boring Scolytidae appeared to play some role in it (KaLSHOven 1954).

Among the occasional host trees listed here, Vitex pubescens belongs to the same family of the Verbenaceae as the teak tree, and it also serves as a foodplant for the primary Cossid borer, Xyleutes ceramica. Still only the single case of attack by $X$. destruens was observed and no infestation occurred in a plot of 6 trees, notwithstanding they harboured the Cossid borer and were standing in a 7-year old plantation in the heavily infested Bandjar area.

Out of the 14 other occasional hosts of X. destruens enumerated, 4 belong to the extensive family of the Leguminosae, the other to very different plant tamilies.

Tree species not susceptible to attack

For an understanding of the habits of the borer it is also of interest to know what tree species are not attacked in the outbreak area. In this connection it is worth mentioning that $X$. destruens was not present in the collections of mixed ambrosia beetles extracted from newly dead, single specimens of "kisampang",
Evodia sp., "kikadu", Durio zibethinus, and "kibanteng", not further identified, all in the forest reserve of Mount Gadung near Bandjar, during the search made in August 1932.

Among the trees planted to some extent in admixture with teak in the Bandjar and Banyumas cultivations, X. destruens was never found in Lagerstroemia speciosa and Eugenia polyantha, though these trees were not infrequently inhabited by larvae of the Cerambycid Nothopeus hemipterus Ol.

Other tree species which appeared not to be susceptible to the attack by $X$. destruens in some of the outbreak areas, were: Adenanthera pavonina, Dalbergia latifolia, Leucaena glauca, Cedrela serrata, Swietenia mahagoni and S. macrophylla, Bixa orellana, Bischofia javanica.

Furthermore it may be mentioned that no attack by the borer has been reported in plantations of Ceiba pentandra (cotton tree), Coffea, Cinchona and Thea, Palaquium (getah pertja) and Hevea braziliensis, growing in the neighbourhood of teak plantations or adjacent to natural mixed forests. Nor has the borer ever been found in one of the many fruit tree species growing in such a variety in shady groves in the plains and hills of Java.

Concluding these observations and the data enumerated in the previous paragraph it may be stated that $X$. destruens will attack a number of different kinds of trees, but cannot be classified as polyphagous. On the contrary it shows a distinct degree of selectivity. However, the borer shows the same preference for certain specimens of the additional hosts as noted in teak, viz. selecting the biggest trees in a stand, and the basal parts and wounded portions of the trunks. Occasionally it apparently attacks dying trees in the company of secondary shot-hole borers, but it does not breed in this medium in large numbers. In no instance outside the teak and cacao plantations conditions have appeared to be favourable for a build-up of large populations, but this may in part be attributed to the fact that the additional host only occurred singly or in a few numbers and not in extensive uniform plantations.

\section{PARTICULARS CONCERNING THE OUTBREAKS}

Percentages of infestation in plantations of different ages

The first extensive survey of the distribution and percentage of infested trees in the Bandjar area was carried out in the Mount Babakan Reserve at ca $250 \mathrm{~m}$ 
altitude, in 1931/1932. Teak growing had been started here in 1916 in two isolated plots of $30 \mathrm{ha}$, the planted area being extended annually with new plantations ranging from 50-190 ha, which had gradually become linked up, covering some 800 ha and including 650 ha of 4-16 years old.

The highest figures were found at that time in the compartments 6-9 years old, which had 18-24\% of infested trees on an average, the percentage ranging from $30-50 \%$ in some centres-as counted in plots of 100-200 trees-and from 5-10\% in the least infested parts. The overall infestation was much more severe than the first infestation observed in Batang in 1918 (see p. 5), where only $5 \%$ of the trees had been attacked in a part of an 8-year old plantation, which plot was 2.5 ha in extent.

In the Bandjar plantations of 10-15 years old, the highest figures did not exceed $25 \%$ in some plots and were $10-20 \%$ on an average.

As for the youngest susceptible compartments those of 4 and 5 years old showed percentages ranging from 2-17 and 4.5-28\% respectively for various plots and averages of 7.5 and $13 \%$.

Somewhat lower figures were found in another area, situated at some distance from the main complex and covering $300 \mathrm{ha}$, which included $135 \mathrm{ha}$ 12-15 years old, and 100 ha 4-5 years old.

A few countings in plots of 100 trees made at Bruno, Kedu, in 1931 (see p. 6) showed $25 \%$ of trees infested in a 7-year old plantation and as many as $40-75 \%$ and $55-75 \%$ in 8 and 9 year old plantations respectively, therefore still higher figures than in the most severely attacked parts in the Bandjar area.
Several data, better comparable than the latter with those of Bandjar, were obtained by surveys carried out by the trained Bandjar personnel in the western part of Banyumas, near Madjenang, in 1935. Here numerous plantations of different ages, up to 15 years old, were to be found. In contrast to the Bandjar situation they were widely scattered over the area, at elevations of 100-400 m and consisted only partly of pure teak, the other part being composed of $50 \%$ teak and $50 \%$ of another tree species. However, the general topography of the area and the adjacency of natural mixed forests were the same as in Bandjar.

Some fairly high figures of infestation were found here in plantations $12-15$ years old where $10-20 \%$ of the trees had been attacked and local infestation in the centres of the outbreak places had reached 30 $50 \%$. For the rest the figures noted in plantations of this age differred widely, infested trees were sometimes found only sporadically or were entirely lacking.

In plantations 7-11 years old no higher figure was found than $7 \%$ of infested trees. Most of the youngest plantations investigated and 5-6 years old, had even remained free from the infestation.

No clear difference was found for the infestation of the teak trees in pure and mixed cultivations.

\section{Repeated assessment of infestation with increasing age}

The percentage of infested trees early found in plantations of different ages in Bandjar, which were mentioned in the preceding paragraph already gave useful indications as to the course of the infestation with increasing age of the plots. It was thought, how-

TABLe 2.

Repeated assessment of infestation percentages

\begin{tabular}{|c|c|c|c|c|c|c|c|c|c|c|c|}
\hline \multirow{2}{*}{$\begin{array}{c}\text { No. } \\
\text { of } \\
\text { plot }\end{array}$} & \multirow{2}{*}{$\begin{array}{c}\text { Age } \\
\text { (years, } \\
\text { months) }\end{array}$} & \multicolumn{2}{|c|}{ Percentages } & \multirow{2}{*}{$\begin{array}{c}\text { No. } \\
\text { of } \\
\text { plot }\end{array}$} & \multirow{2}{*}{$\begin{array}{c}\text { Age } \\
\text { (years, } \\
\text { months) }\end{array}$} & \multicolumn{2}{|c|}{ Percentages } & \multirow{2}{*}{$\begin{array}{c}\text { No. } \\
\text { of } \\
\text { plot }\end{array}$} & \multirow{2}{*}{$\begin{array}{c}\text { Age } \\
\text { (years, } \\
\text { months) }\end{array}$} & \multicolumn{2}{|c|}{ Percentages } \\
\hline & & aver. & $\max$. & & & aver. & $\max$. & & & aver. & $\max$. \\
\hline $\begin{array}{l}1 \\
2\end{array}$ & $\begin{array}{c}4 \mathrm{y} . \\
10 \mathrm{y} . \\
4 \mathrm{y} . \\
10 \mathrm{y} . \\
5 \mathrm{y} . \\
8 \mathrm{y} . \\
5 \mathrm{y} . \\
10 \mathrm{y} .6 \mathrm{~m} .\end{array}$ & $\begin{array}{c}7 \\
19.5 \\
3 \\
31.5 \\
\\
6 \\
14 \\
\\
3 \\
8.5 \\
.\end{array}$ & $\begin{array}{c}17 \\
38 \\
22 \\
36 \\
\\
6.5 \\
24 \\
\\
15 \\
19\end{array}$ & 5 & $\begin{array}{c}5 \mathrm{y} .6 \mathrm{~m} . \\
7 \mathrm{y} . \\
10 \mathrm{y} .6 \mathrm{~m} . \\
6 \text { y. } 6 \mathrm{~m} . \\
8 \mathrm{y} . \\
7 \mathrm{y} . \\
8 \mathrm{y} . \\
12 \text { y. } 6 \mathrm{~m} . \\
7 \mathrm{y} . \\
8 \mathrm{y} .6 \mathrm{~m} . \\
11 \mathrm{y} .6 \mathrm{~m} .\end{array}$ & $\begin{array}{l}25 \\
29.5 \\
22 \\
\\
20 \\
22 \\
\\
18.5 \\
19.5 \\
12.5 \\
\\
20 \\
23 \\
18\end{array}$ & $\begin{array}{l}40.5 \\
46 \\
35 \\
\\
28.5 \\
29 \\
\\
34 \\
41 \\
24 \\
\\
36 \\
37 \\
31\end{array}$ & 12 & $\begin{array}{c}8 \mathrm{y} . \\
9 \mathrm{y} .6 \mathrm{~m} . \\
12 \mathrm{y} .6 \mathrm{~m} . \\
9 \mathrm{y} . \\
10 \mathrm{y} . \\
15 \mathrm{y} . \\
12 \mathrm{y} . \\
17 \mathrm{y} .6 \mathrm{~m} . \\
13 \mathrm{y} . \\
18 \mathrm{y} .6 \mathrm{~m} .\end{array}$ & $\begin{array}{l}22.5 \\
27 \\
19.5 \\
10 \\
14.5 \\
11 \\
\\
19 \\
7 \\
16 \\
9\end{array}$ & $\begin{array}{l}47 \\
55 \\
57 \\
\\
43.5 \\
26.5 \\
21 \\
\\
20.5 \\
19.5 \\
\\
20 \\
26\end{array}$ \\
\hline
\end{tabular}


ever, that more complete information could be obtained by repeating the countings in certain plots-or at least in the same parts of the plantations-after a lapse of time. Such countings were carried out in 1934-1938. The main data found are tabulated here.

These figures again point to a somewhat varying percentage of infestation to be found in plantations of the same age. It is also evident, again, that the main increase in the number of infested trees takes place in the first years after the plantations have become susceptible to the borer attack, that is at the age of 4-8 years. After the trees have reached an age of about 9 years there is little more increase and even a decrease may set in, particularly in the average infestation of different plots of the same stand. This must, however, rather be attributed to the removal of numbers of infested trees during the thinning operations than to a number of trees having been left by the borer and their holes having healed.

Percentages of infestation, cited in the literature

Some of the figures, so far given, have been mentioned only in service reports and none of them have yet been published.

However in a paper by Ferguson (1949) data on the borer's infestation are quoted which had been computed by a graduate forest officer for plots of $1 / 4 \mathrm{ha}$ in a series of plantations covering 16 ha in the Bondowoso district in East Java, at $400-700 \mathrm{~m}$ altitude.

They mention $14 \%$ of trees infested in a 5-year old compartment, the figure rising abruptly to some $45 \%$ for the 6 and 7 year old plots, and with further annual increase of $10-20 \%$ reaching $90 \%$ in the 10 -year old part. These figures differ markedly from those found in Bandjar and Banyumas and they are even considerably higher than those of Bruno. However, some doubt may be expressed as to their correctness, as the investigation was made without the assistance of an entomologist or phytopathologist. So it appears possible that a part of the infestation noted was caused by other borers in living trees, notably $X y$ leutes ceramica and Monohammus rusticator, both of which have been found abundantly in similar areas. There is a particular reason for this assumption in the fact that it is stated that $7-20 \%$ of the borer-attacked trees had died as a result of the infestation. Now, death of trees exclusively as a result of attack by $X$. destruens has not been observed in any of the other outbreak areas. Probably the trees in Bondowoso had succumbed owing to a root-disease, another phenomenon currently noticed under similar conditions. Fin- ally it is important that the percentage of $X$. destruens infestation in the 10-year old plantation of the same locality was estimated to be $60 \%$ by the forest conservator F. W. RAPPARD-well versed in zoological matters-as recorded also by FERGuson.

An impressive list of figures has further been given in the more recent paper of VAN ALPHEN DE VEER (1956), his data being based on countings and estimations of personnel of the Forestry Service in 1952 1954. For our study they are particularly interesting as they show how the infestation in the Tjiamis/ Bandjar area has persisted since the period 1930 1938. The numbering and naming of the plots is somewhat different from those used in the early period and the size of the plantations is not mentioned. However, the data about the year of cultivation give sufficient points of contact.

It appears that the highest figures noted for Bandjar have again been found in the Mount Babakan area, viz. $21 \%, 27 \%$ and $35 \%$ for 6,8 and 12 year old plantations respectively. The plantations which were 2-4 years old in 1931 and had reached the age of 23-25 years in 1952 were found to be infested for as much as $40-50 \%$. Two of the oldest compartments, 32 years of age in 1952, figure with $27 \%$ and $28 \%$ infestation.

Again, the plantations in East Java, all growing at the relatively high altitude of $350-600 \mathrm{~m}$ show very high figures, viz. $40-80 \%$ at the age of $10-14$ years. The possibly exaggerated figure of $90 \%$ infestation is still given for 9-14 year old plantations at $700 \mathrm{~m}$ in the most eastern part near Bondowoso.

\section{Number of holes per tree}

To establish the density of the borer population in the plantations the ascertainment of the number of holes per infested tree is at least as important as that of the percentage of trees attacked. Therefore several countings were made of the holes, up to $1.75 \mathrm{~m}$ from the base, on 40-100 trees in order to obtain data relative to this question. It appeared that the figures again showed a very wide range, viz. from a few holes per tree to some hundreds. Under the conditions prevailing in the Bandjar area badly infested plots from 5 to 6 years old had an average of 25-35 holes per tree attacked, rising from 35 to 60 holes per tree in plantations of 7-9 years old. In one instance an average of not less than 65 holes per tree was found in a heavily infested plot of 4 years and 6 months old. The maximum number of holes amounted to some 200 in a single tree.

In 7 plots the gradual increase of the holes was followed over a period of from one to two years by 
fortnightly inspections. In several of these plots the numbers of holes appeared to double or even triple in one year's time, giving higher figures than found in other plots of the same age. Maximum numbers of 200-350 additional holes were counted on a single tree, and in an exceptional case the number of holes in a 6 year old tree rose in 1 year from 160 to 830 . It is suspected, however, that the treatment of the trees during the repeated inspections-viz. the marking of the holes with tar numbers and with nails driven into the wood, besides the artificial wounding on some of them-made them exceptionally attractive for the borer. Generally a tree carrying a large number of original holes continued to show proportionally large numbers of additional borings. In the other extreme only a few holes were made in the beginning and very little increase, if any, followed.

From the figures given in this paragraph and the preceding one it may be concluded that the number of holes per tree may show a more rapid increase than the percentage of trees attacked.

As will be readily understood, not all borings lead to the formation of complete galleries and a successful raising of brood. It has even been found, in some instances, that one half of the tunnels remains unfinished. Still, for a tree containing only a score of well established tunnels, this means that hundreds of borer adults may be developing in it, and this number may increase to thousands if a tree is heavily infested from the base up to the crown. In fact in one instance some 250 beetles were found emerging from the basal portion-one meter long-of an infested tree which had been brought to the laboratory.

\section{Distribution of the outbreak areas}

As far as experience goes outbreaks of the borer have never occurred in the main teak area, which is found between the lines Semarang/Surakarta in C. Java and Surabaya/Kediri in E. Java (see map). Here pure teak stands of various ages cover the low ridges of marl soil in the northern part, with the well known centres of management and exploitation in Purwodadi, Blora, Rembang, Ngawi, Tjepu and Bodjonegoro, and on similar terrains and also on laterite soils in the southern part situated round the centres Madiun, Ngandjuk, Djombang, etc. The teak-bearing hills seldom rise to above $200 \mathrm{~m}$, the soil is often rather poor and little wild growth of various other trees is to be found mainly along the ravines.

Still, $X$. destruens is not wholly absent in this area as the following observations may show.

A single tree, $20 \mathrm{~cm}$ thick and $20 \mathrm{~m}$ high, was found to be heavily infested from its base-even be- low the soil surface-up to $7 \mathrm{~m}$ in a plantation in the forest range of Banglean, X. 1924. It was one of the best developed trees in the stand. Although a premium was promised to forestry personnel for the finding of other infested trees only one other example could be discovered in the neighbourhood. Both trees were felled and no further occurrence of the borer was reported.

Old galleries of the borer, the entrance hole covered by one or two annual rings of new wood were noticed in a piece of timber in the forest range of Blungun near Tjepu, XII, 1925 (Pl. I, fig. 2). No infestation of trees was to be discovered in the neighbourhood at the time, but some trees carrying traces of the borer were noticed in other compartments of 11-15 years old, the next year. One of them was a tree of $24 \mathrm{~cm}$ diameter which after having been felled and split proved to have a score of galleries only in a portion of the trunk, 6-8 $\mathrm{m}$ above the base. Both these observations and the former were reported by the assistant forest entomologist, F. VerbeEk.

Typical tunnels of $X$.destruens were found in a piece of furniture in Gundih, made from so-called "djati doreng", a variety of teak timber with dark grain, which is in great demand, XII. 1922.

In some piles of sleepers hauled from the forest of Tobo (near Bodjonegoro) a single piece was found to be perforated by the tunnels of the borer, X. 1926, and out of 150 joists in a timber yard at Kedunggalar (W. of Ngawi) six were riddled by the holes, XI. 1927. No investigations into the original stand of the timber were made in these instances.

These few data, all that are available, show that $X$. destruens, though living in the teak area proper, does not find there suitable conditions for propagation except in single or small groups of trees.

Outside the main teak area several teak forests of much smaller extent, more isolated and often bordering natural high mixed forests of other species, are to be found in other parts of the country. They are situated west, south and east of the main area, some notable strips being found in the northern plains and hills of C. Java, in the southern parts of Jokjakarta, Madiun and Kediri and on some very dry areas along the $\mathrm{N}$. coast of the eastern-most districts of Pasuruan and Besuki (see map on p. 18).

It is in some of these scattered forests that smaller outbreaks of $X$. destruens occurred, for instance near Batang, Tjomal, and Bodja, in East Banyumas and near Kepandjan. However, the heaviest and most lasting outbreaks developed in teak plantations which were started in places where the tree did not occur 

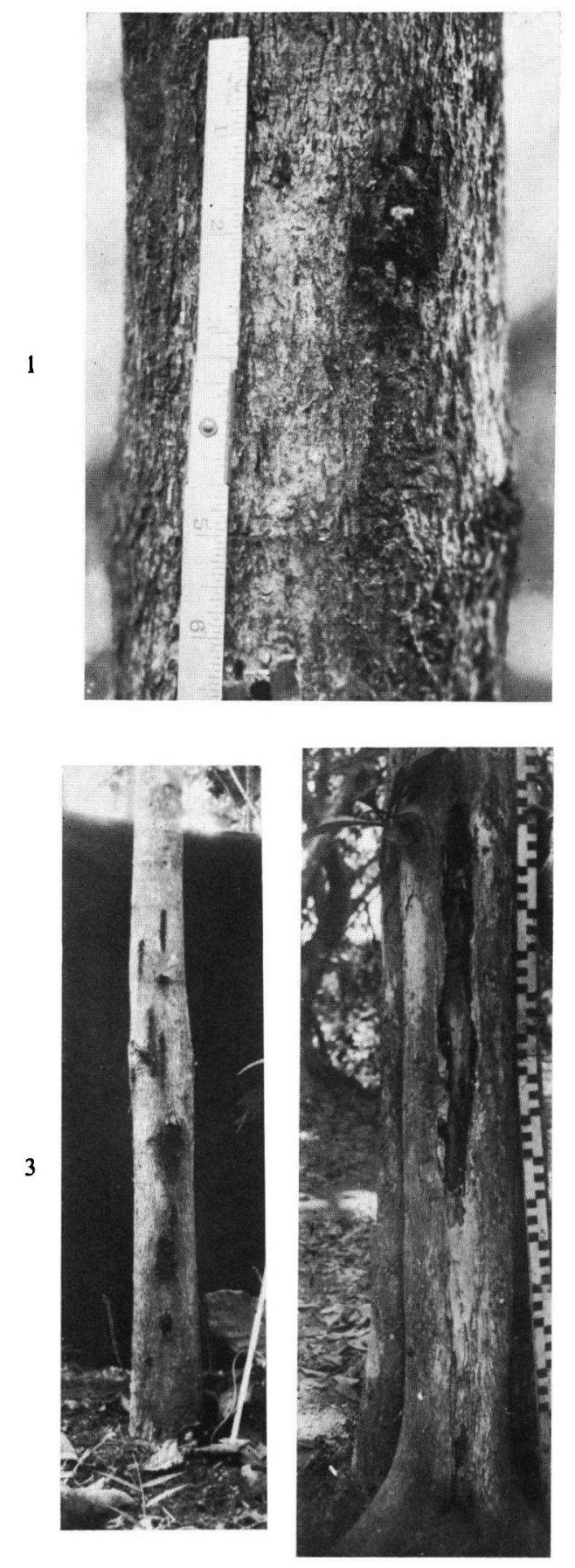

4

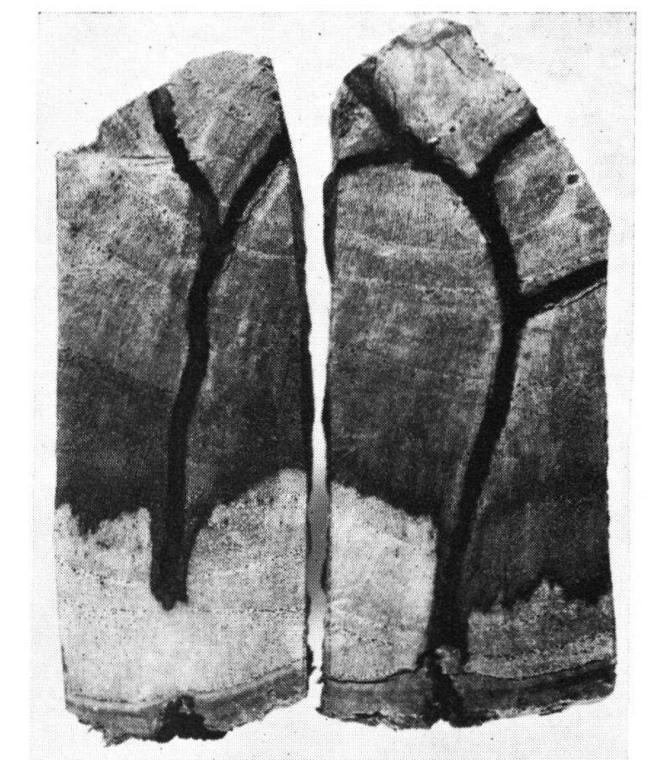

2

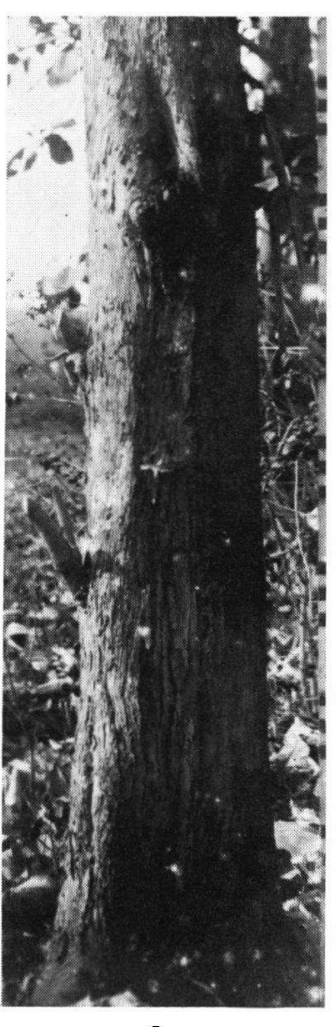

5

Fig. 1. Cylinders of frass produced by $X$. destruens beetles boring into a teak trunk where a Cossid hole is situated (p 7). Fig. 2. Cross sections showing old galleries of $X$. destruens covered by a new wood layer (note the annual rings and the discoloration of the wood) (p. 16, 20). Fig. 3. Characteristic stains caused by X. destruens attack on a young teak tree which shows the sign of Cossid infestation at $1 \mathrm{~m}$ from the base (p. 7). Fig. 4. Mature teak tree with a large, discharging wound which is infested by $X$. destruens along its margin (p. 11). Fig. 5. Local infestation by $X$. destruens of mature teak tree at $1.5 \mathrm{~m}$ from the base (p. 11). Fig. 6. Longitudinal section through an old cancerous cacao trunk riddled by the holes of $X$. destruens (p. 12). 
PLATE II

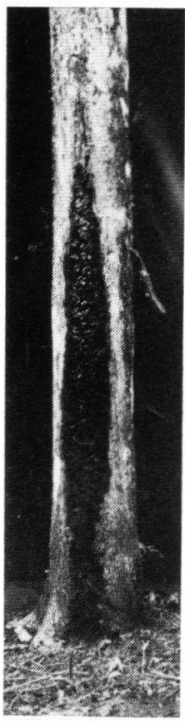

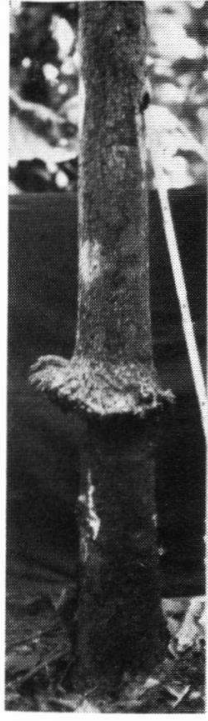

8

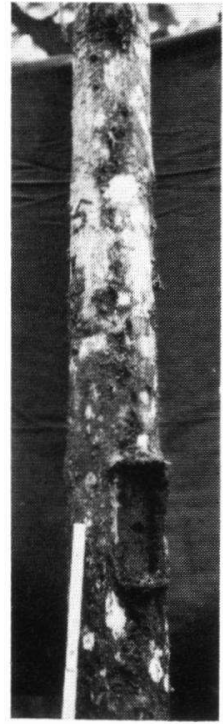

9

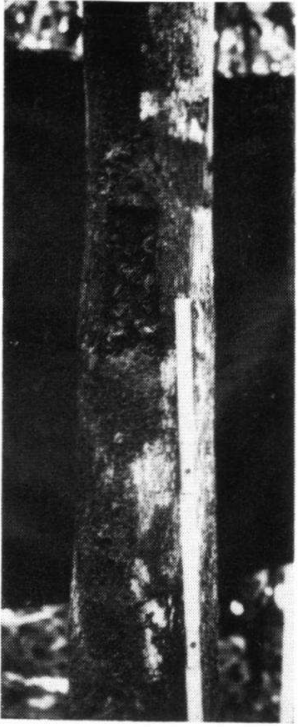

10

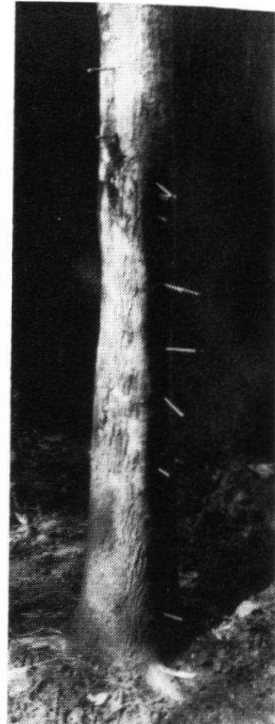

11

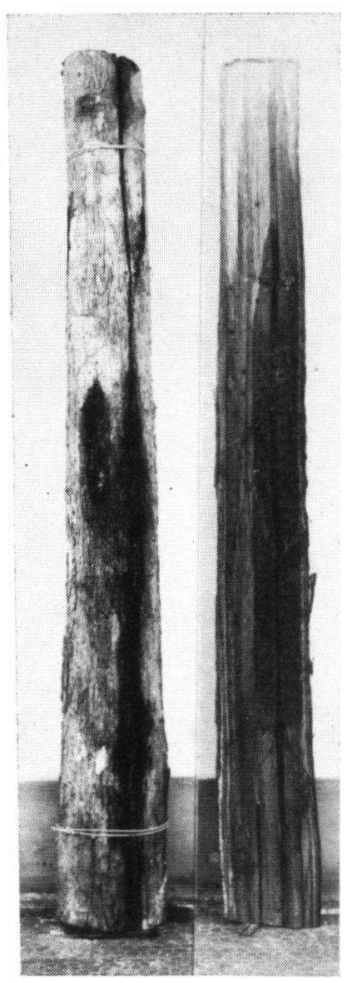

12

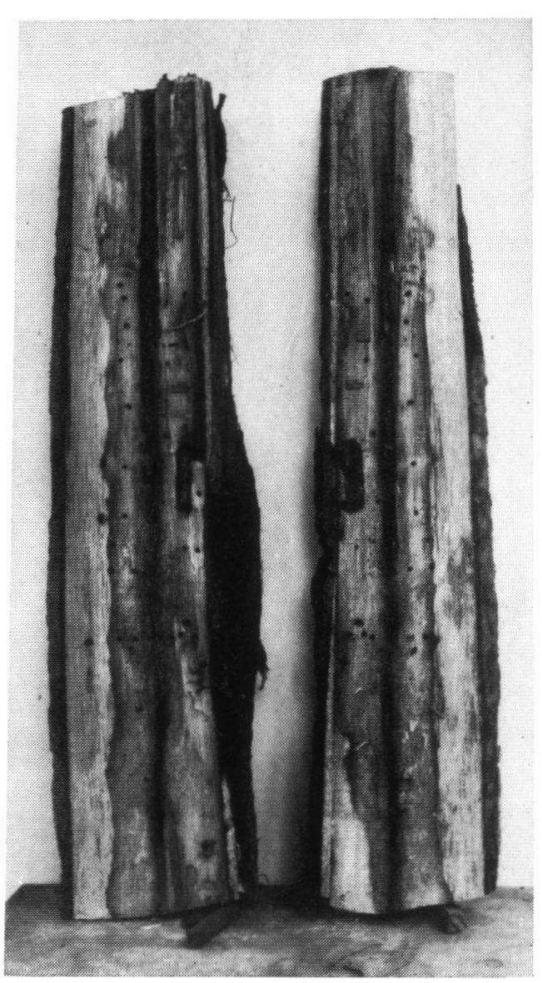

13

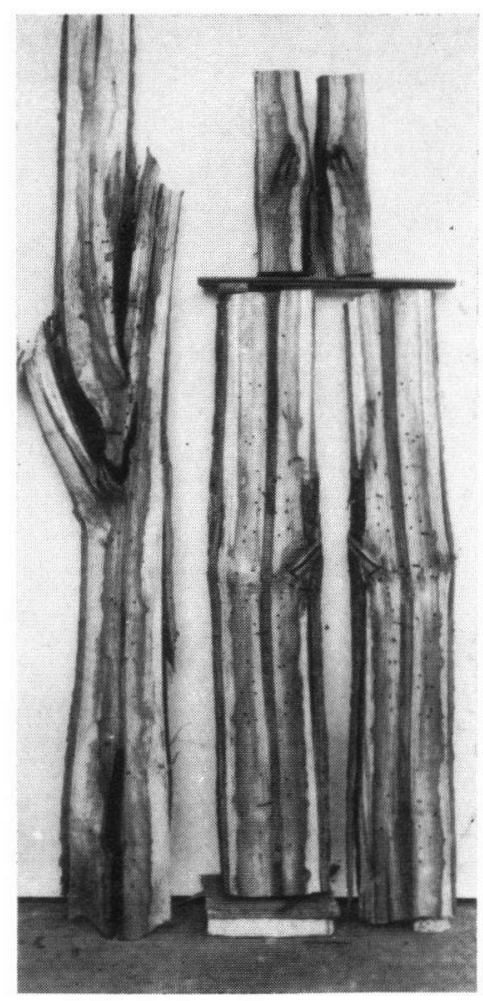

14

Fig. 7. Discharge of dirt along a fissure in a young teak tree (p. 8). Fig. 8. Thick collar of callus tissue formed at the upperside of a ring cut (p. 10 and 17). Fig. 9. Artificial wounds made in the bark of a young teak tree (p. 9). Fig. 10. A similar wound which has become infested by $X$. destruens as shown by cylinders of frass pushed from the holes (p. 9). Fig. 11. Experiment with clogging the holes with bamboo pegs (p. 20). Fig. 12. Teak trunk with fissure which has become infested by $X$. destruens (note the black specks of the holes at the upper side of the diseased wood in the longitudinal section shown at the right) (p. 8). Fig. 13. Infestation by $X$. destruens where the tree has been damaged by the longicorn borer Monohammus rusticator. In the centre the hook-like pupal cell is visible (p. 7). Fig. 14. Left: Infestation at the place where a young tree has formed a double furcation, and where a grub hole of the Cossid borer is also present. Right: Infestation by the $X$. destruens borer at the place where the snag of a former side branch occurs (p. 8). 
naturally, or scarcely so, as Bandjar, West Banyumas, S. Smeru and Bondowoso. In the last three instances the plantations were situated rather high up in the hills and on the slopes of the volcanic mountains, at an altitude of $400-600 \mathrm{~m}$.

On the accompanying map which shows lines and contours taken, in combination, from the "Boschkaart van Java en Madoera" (appendix of the "Verslag Dienst Boschwezen over 1926") and the map concerning the Rainfall Types of Java (ScHmior \& FERGuson 1951) the boundaries of the main teak forests and the sites of the outbreak areas are plotted. At the first glance it can be seen that the outbreaks have all occurred outside the teak area proper or in marginal places.

\section{Local conditions in the outbreak areas}

During my first visits to the infested plantations of Bandjar and Bruno it was soon realized that the local conditions in climatic and other respects differred markedly from those prevailing in the typical teak forests along the northern coast of C. Java and in E. Java, with which I was familiar.

The predominant and most differentiating factor is the climate which is characterized in the latter area by the alternation of a rainy season-the wet monsoon-lasting from October to April, and a pronounced dry season-the dry monsoon-from May to September, while in the outbreak areas the rainfall is more abundant and more evenly distributed over the months. Of course this has a strong bearing on the vegetation and fauna. The most interesting feature is that the teak in its main area of distribution sheds its leaves in the beginning of the dry season and stands bare for several months, to put on new flush when the rains come again but that in the teak plantations in West Java the trees mostly keep their foliage the whole year round and the renewal of the foliage takes place inconspicuously. This results in a faster growth in girth and height.

The influence of the heavier and more regular rainfall also makes itself felt in Bandjar in the kind of vegetation. A rich growth of various trees, shrubs and large herbs is not only to be found along the water courses but also in the teak plantations and it includes much bamboo (Gigantochloa apus), Pandanus, second growth of palms-including Arenga obtusifolia-, wild banana (Musa zebrina), and robust Zingiberaceae. Among the soil covering plants Solaginella, a climbing fern with hand-shaped leaves, Cyperaceae, and the Graminaceae Panicum maximum and Anastrophus compressus are very common. This vegetation includes elements which are absent or much rarer in the main teak area, where the climate approaches the semi-arid type.

With regard to the fauna in Bandjar, the abundant occurrence of earthworms is striking and is even increased by the activities of wild pigs churning up the soil surface over large stretches in search of the worms. Planaria is often seen among the litter. Termite life is even more abundant and diversified here than in the typical teak forests and includes Coptotermes curvignathus. A cicada that produces a kind of whistle alternating with a lower-pitched piercing sound-called "jumenè" in the sundanese languagemakes itself very noticeable during the day time.

A very important detail is that, besides from the borer attack, the teak stands suffer considerably from other diseases and pests either not occurring at all or to a less degree in the teak area proper. Not rarely trees are killed by root disease, partly caused by Fomes noxius and Xylaria thwaitesii (KALSHOven 1935 p. 55, 1936 p. 78). Another fungus Helicobasidium, which envelops the root collar and base of the tree with a greyish velvety growth is very common in some places. It appears to affect only part of the root system and does not kill the trees outright (l.c. 1935). The density of the Cossid borer Xyleutes ceramicus, appears to be larger than usual, and the bark and sapwood borer Monohammus rusticator, found in teak in only a few places, is much in evidence here. Several details about this damage and its relation to the Xyleborus attack have been mentioned before (supra p. 7).

Three other factors affecting the teak plantations in the Bandjar area are of interest. First, a great deal of the teak has been planted on terrains newly cleared in primeval forest. This seems to favour the rapid growth of the trees, even more than the abundant rains.

In the second place the area appears to be rather often visited by gales which has resulted in the occurrence of large groups of trees broken and damaged or bent at the top.

Thirdly the wounds in the bark appear to heal remarkably slowly, although often much callus is formed (Pl. II, fig 8). Apparently the healing is counteracted by other agencies. One of these is constituted by the termites, which extend their galleries on the trunk and have plenty of opportunity to locate the damaged places, and feed on the exposed tissues, thereby enlarging the wound and hindering its occlusion.

Particularly the relatively small holes of the Cossid borer do not close readily but keep discharging brownish matter. As a result these holes which are 

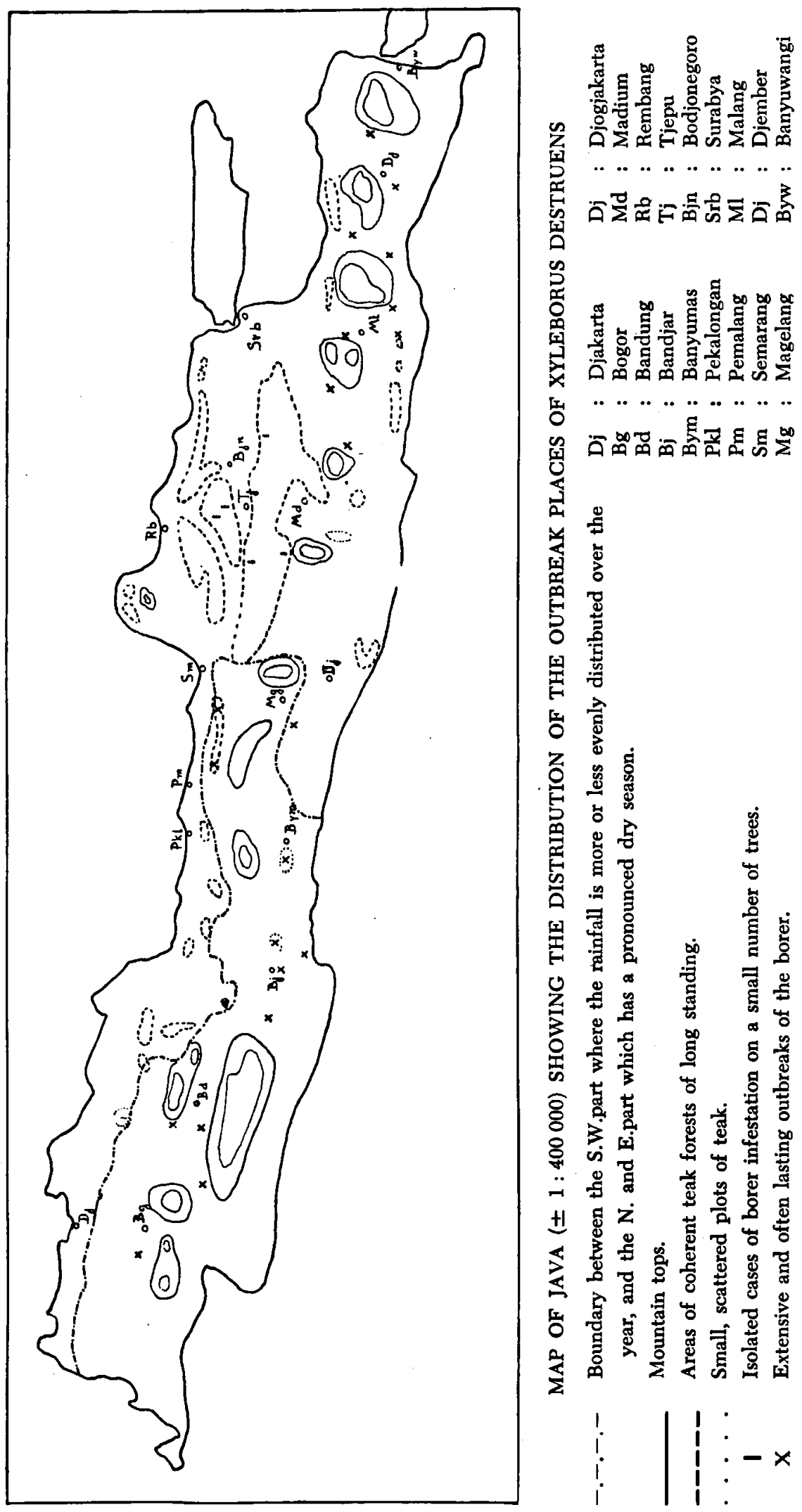
normally overlooked, are rather conspicious in these plantations.

From these data it will be clear that plantations where outbreaks occur are characterized by the presence, during the greater part of the year; of great numbers of trees that are particularly suited for the breeding of the borer, viz. trees of rank growth, containing full sap and often showing discharging wounds. The main cause of the development of the outbreaks, therefore, may be this very circumstance. Possibly the abundant rain and the humid atmosphere also favour the borer directly to some extent.

\section{Centres of infestation and contamination}

Of course, conditions are not uniform all over the plantations of some size as there are the usual variations in topography, soil quality, former occupancy of the terrain, and so on. These must be the reason why an infestation is not spread evenly over large plantations of uniform age, but shows considerable differences in different parts. The largest concentrations of the borer have been found in valleys, on steep slopes of ravines, and along the water courses, while lower percentages of infestation occur on tops and ridges. This clearly corresponds with the differences in the growing conditions of the trees in different circumstances.

It has also been observed that trees lining the paths which cross the plantations, and those standing near the borders of the planted area are often attacked in larger numbers than those growing in the interior of the plantations. The explanation of this phenomenon may be the fact that these trees are more easily accessible to the swarming beetles. The occasional crowding of the borer along the borders of the plantations may also point in the direction of contamination by adjacent older plantations, where the infestation has started at an earlier date. The close neighbourhood of original mixed high forest, which has been found to be a natural habitat of the borer, may have the same effect.

It is evident, moreover, that in areas where an extension of the planted area is effected annually -and this is the case in Bandjar-, the spread of the borer to new sites is much facilitated. These are no indications as to the distances the swarming beetles may cover. I have the impression, however, that the borer once it is settled in a suitable site, has a tendency not to spread further than the immediate neighbourhood and that new beetles emerging from the galleries are even inclined to re-enter the same host tree. This circumstance would be an additional explanation of the provenience of the centres of high infestation.

\section{Limiting factors}

Notwithstanding the fact that very many infested trees were inspected and a fair number of tunnelsystems examined as to their contents, no specific parasite or predator of the borer has been found. In fact single specimens of a Staphylinid and a small Brenthid beetle were collected only once during a careful examination of infested trunk fragments. A few mites were observed on caged lengths of infested trunk portions, but not on the trees in the fields. Ants have been seen to carry off dead specimens of the beetle expelled from the holes, but they do not penetrate into the galleries

Sufficient evidence has been gathered, however, that the intrusion of a dipterous larva in the galleries apparently impeded the normal development of the brood (Kalshoven, in press). Several instances were noticed where in a short, apparently.recent tunnel only the dipterous larva was found and no beetle. This seems to suggest that the former insect had caused the latter to leave the tunnel. Where a larva establishes itself in an older gallery system, the clogging of the entrance by its body may be the reason that the brood of the borer comes to an end. In fact a kind of putrefaction of the liquid in the gallery has been found in a few cases.

Of course there must be other reasons why a beetle does not complete its gallery, for the investigations have shown that the number of short empty tunnels is rather large. No exact figures can be given about the percentage of unfinished tunnels but a few preliminary indications seem to indicate that in certain cases only one half of the tunnels initiated lead to their completion and the raising of brood. In a few cases it was apparent that the beetle had bored into a wounded part of the trunk where the wood was already infested by rotting organisms, which must have hindered the introduction of the fungus with which the borer is associated. In most cases, however, it may be that the female beetle had failed to find the necessary conditions as regards food and moisture in the place chosen for entrance into the host.

For the occurrence of abnormally small quantities of brood in some well worked galleries a few explanations may be ventured: 1/ the rare occurrence of male individuals with the possible consequence that the young female beetles do not get fertilized in due time (no indication of parthenogenesis has been found), 2 / the frequent crowding of the tunnel sys- 
tems in certain portions of the trunk, which might conceivably result in a shortage of nutritional substance-in the widest sense of the word-for all the broods, 3 / the tendency to cannibalism which the larvae have shown under laboratory conditions and which might also reveal itself under less favourable conditions in the field (KaLSHOven, in press).

As for the first mentioned factor it was interesting to see that GADD (1949) in his studies on Xyleborus fornicatus in Ceylon came to a similar conclusion where he writes: "the frequent finding of small broods, that do not include a male suggests that many females are not fertilized and consequently do not reproduce".

With regard to the available moisture there may be too much of it or too little. Some of the infested trees have appeared to produce an excess of fluid and in rare instances eggs have been found in very wet places of the tunnels. Old unhatched eggs have also been noticed.

Generally speaking, however, an abundance of sap in a tree appears to be necessary for the borer, as has been mentioned before. The fortnightly assessments of the infestation of marked trees have shown that the increase in the number of new holes may be reduced to a fraction or come to a stop during rainless periods, which-even under Bandjar conditions-may last for some 4-6 weeks, particularly in the months of September/October. In other instances no slackening in the spread of the borer has been observed during dry periods, the infested trees perhaps growing on well watered sites.

\section{SOME SILVICULTURAL ASPECTS}

\section{Consequences of the attack for the host tree}

No outward signs of any injurious effect of the attack on the general condition of the tree are to be observed. There is, for instance, no loss of foliage, neither is there a slowing down of the girth-increment or the growth in height.

In some instances a swelling of the infested basal part of a tree has been observed (also mentioned by vaN Alphen De Veer, 1956). It is not clear, however, that this swelling is an effect of the infestation and it seems more likely that trees with thick bases or such as are branched and forked near the foot are particularly susceptible to attack by the borer.

However, the trunks of infested trees when split longitudinally, show a distinct discoloration of the wood, which may even extend to a distance of six metres from the place of infestation. The stain consists mostly of blackish or brownish zones with dark margins (Pl. 1, fig. 2) and enclosing sound parts, but all kind of hues may be seen, even a reddish tinge, and the timber looks spotty. As a rule the stain is most advanced along the pith. In addition the exposed wood often has a very bad odour (called "banger" in the sundanese language).

It was easy to demonstrate with iodine solution that there was a definite depletion of the starch content in the stained parts of the wood, while starch was still present in the sound enclosures. Here the amount of starch appeared to be the same as was found in sound trunks throughout. This observation was made at the end of the month of October in Bandjar, at a time when the trees had some new leaves besides the remnants of old foliage.

Though this disappearance of starch might implicate a loss of reserve substances to be used for putting on new flush and wood layer, nothing pointed in this direction. An experiment showed that $1 \mathrm{~m}$ high stumps of felled infested trees formed new suckers in the same quantity and length as the stumps of unattacked trees.

In agreement with the slow recovery of all kind of wounds on teak trees, so noticeable in the Bandjar area (p. 17) and in similar localities, the closing of the bore holes of $X$. destruens has also appeared to be much retarded. This may be attributed in part to the activities of the beetle in the entrance and the continued exudations. In some cases it has been observed that an oval necrotic patch had developed in the cambial zone surrounding the hole. It is evident that under these circumstances the occlusion with callus growth of even such a small hole may be delayed for a considerable time.

\section{Attempts to control the attacks of the borer}

While the prolonged studies of the borer in the years 1932-1938 aimed in the first place at reconnoitring the distribution of the outbreaks and their enduring prevalence in some places, it was also hoped that a method or methods might be discovered that would enable us to arrest the attacks or reduce their ill effects.

A large-scale experiment was made with plugging the holes with bamboo pegs in order to stifle the beetles and their brood in the galleries. As was said above this method did not result in the insects being killed for $100 \%$. Besides, it was a very arduous task, particularly on badly infested trees, which got a very "bristled' outlook after the treatment (Pl. II, fig. 11). Moreover, renewed attacks appeared to occur on the trunks treated.

The systematic removal of all the trees attacked during regular thinning operations was another method which was tried. It appeared to be applicable only in the youngest plantations which were not yet heavily infested and it required very careful working so that no trees with a slight, inconspicuous infestation might be overlooked. In these plantations 40 to $55 \%$ of all trees were removed during the first thinnings.

In somewhat older plantations, which had a high degree of infestation, the forestry personnel was rightly opposed to the removal of all the trees that had been attacked, which were nearly all well-developed, dominating specimens. Their removal would have caused gaps to be made in the canopy, which in its turn would have led to the plots running wild. That this was a real danger was proved by the fact that several places where there had been outbreaks of the borer already showed a tendency to running wild as a result of the death and breakage of trees by root disease and gales.

Besides, the felling of considerable numbers of badly 
infested trees may lead to the emergence of large numbers of beetles which will now concentrate their attacks on the greatly reduced number of trees remaining in the stand, and also contaminate adjacent plots. Therefore it will be clear that large scale felling of trees must immediately be followed by measures calculated to reduce this danger. In this connection it is recommended to carry out the thinning and felling operations in a dry period and to remove the poles and logs rapidly to places outside the forest. In certain areas of small extent throwing the poles into the water and keeping them submerged for at least a fortnight has proved to be sufficient to kill the beetles and their brood.

\section{Prevention of further losses}

When it became evident that the bore-infestation in certain areas as, for instance, Bandjar was not of a temporal nature but had assumed a permanent character affecting all plantations over 5 or 6 years old, some forest officers concerned-and Ir. F. J. APPELMan was among them-suggested that the planting of teak should be discontinued in these localities. This suggestion was endorsed by some authorities at Bogor. However no definite directions were given. This explains why in other districts forest officers who had no first hand knowledge of the borer pest of teak, and who were much impressed by the rapid growth of teak and the growing demand for teak timber in the home market and for export, started new plantations in some places outside the main teak area. But again, this soon proved to be a risky business.

Unless one is satisfied with growing teak of poor quality, only suitable for the cheapest building purposes, the safest way to prevent disappointment and losses seems to be to refrain from the planting of teak in areas where the natural conditions would stimulate too rapid and rank a growth of the tree. For this rapid growth causes the trees to become very susceptible to the attack of the $X$ leborus destruens borer and to other destructive agencies. Everything should be done not to endanger the just reputation for high quality that Java teak has so far enjoyed.

\section{REFERENCES}

AlPhen de Veer, E. J. van, 1956: Xyleborus destruens. Commun. For. Res. Instit. Indonesia, No. 50, pp. 1-24 (In Indonesian).

Anonymous, 1927: Verslag van den Dienst van het Boschwezen over 1926. Batavia.

Blandford, W. F. H., 1896: Descriptions of new Scolytidae from the Indo-malayan and Austro-malayan Regions. Trans. Ent. Soc. Lond., pp. 191-228.

Ferguson, J. H. A., 1949: Xyleborus destruens in de djati. Tectona, vol. 39, pp. 387-388.

GadD, C. H., 1949: Studies on the shot-hole borer of tea. 4. Life-cycle of the beetle. Tea Quarterly, vol. 20, pp. 61-65.

HaLl, C. J. J. vaN, 1919 and 1920: Ziekten en plagen der cultuurgewassen in Nederlandsch Indië in 1918. Similar report for 1919. Med. Inst. v. Plantenziekten, No. 36 and No. 39.

Kalshoven, L. G. E., 1920: Voorloopig onderzoek van een aantasting van levenden Djati door Xyleborus destruens Bldfd. Tectona, vol. 13, pp 32-55.

Kalshoven, L. G. E., 1925: Primaire aantasting van houtige gewassen door Xyleborus-soorten. Verslag zesde Vergader. Vereen. Proefst. Personeel.

Kalshoven, L. G. E., 1926: Het boschentomologisch onderzoek te Tjepoe. Voordracht op 30 July 1926.

Kalshoven, L. G. E., 1928: De beschadigingen, ziekten en plagen van de djatibosschen op Java. Tectona, vol. 21 , pp. 593-621.

Kalshoven, L. G. E., 1933: Problems of forest entomology in the Netherlands East Indies. C.R. Congres de Nancy.
Un. Intern. Inst. Rech. Forest. 1932. (also: Ve Congr. Intern. d'Entom. July 1932.)

Kalshoven, L. G. E., 1933: in S. Leefmans, Ziekten en plagen der cultuurgewassen in Nederlandsch Indië in 1930. Med. Inst. v. Plantenziekten, No. 81, p. 57.

Kalshoven, L. G. E., 1934-1936: In P. van Der Goor, Ziekten en plagen der cultuurgewassen in Nederlandsch Indië in 19.32. Similar reports for 1933, 1934, 1935. Med. Inst. Plantenziekten, No. 83 (p. 59), 84 (p. 55), 85 (p. 69), 87 (p. 78). The last report also in Tectona, vol. 29.

KALSHOVEN, L. G. E., 1953: Important outbreaks of insect pests in the Forests of Indonesia. Trans. IXth Intern. Congr. Entom. 1951, pp. 229-234.

Kalshoven, L. G. E., 1959: Dr. A. Zimmermann's Java Scolytids identified. Entom. Ber., vol. 19, pp. 224-227.

Kalshoven, L. G. E., in press: The gallery system and the development of the brood of Xyleborus destruens.

RoEpke, W., 1919: Xyleborus destruens Bldfd. (Col. Ipidae) schädlich für Djati (Tectona grandis). Treubia, vol. 1, pp. 68-71.

Schedl, K. E., 1942: Neue Scolytidae aus Java. Tijds. Entom., vol. 85, p. 6.

SChedL, K. E., 1951: Fauna Indo-malayaensis I. Tijds. Entom., vol. 85, p. 6.

Schmmt, F. H. and J. H. A. Ferguson, 1951: Rainfall types based on wet and dry period ratios for Indonesia with Western New Guinea. Kemantr. Perhub. Djaw. Meteorol. dan Geofisik. Verhand. No. 42.

ZeHNTNER, L., 1901: Schorskevers in Cacaostammen. Bull. No. 1, Proefst. v. Cacao te Salatiga, p. 2. 